\title{
IDH Gene Family Mutation
}

National Cancer Institute

\section{Source}

National Cancer Institute. IDH Gene Family Mutation. NCI Thesaurus. Code C129264.

A change in the nucleotide sequence of the IDH1 or IDH2 gene. 